\title{
Assessment of Undiscovered Oil and Gas Resources in the North-Central Montana Province, 2017
}

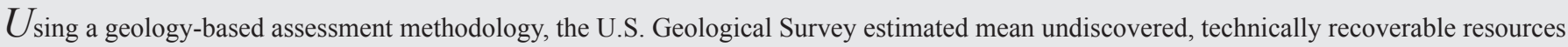
of 55 million barrels of oil and 846 billion cubic feet of gas in the North-Central Montana Province.

\section{Introduction}

The U.S. Geological Survey (USGS) quantitatively assessed the potential for undiscovered, technically recoverable conventional and continuous (unconventional) oil and gas resources in the North-Central Montana Province (fig. 1). The geologic evolution of the province is the result of a series of tectonic events that affected the western margin of North America (Petersen, 1986; Anna and others, 2011). These events include (1) the development of Neoproterozoic rifts and a regional lineament system; (2) an early to middle lower Paleozoic passive margin (Cambrian-Silurian); (3) the east-west trending central Montana trough coeval with the development of the Williston Basin (Petersen, 1986; Maughan, 1989); (4) Late Devonian through Mississippian subduction and compression during the Antler orogenic event; (5) Pennsylvanian uplift and erosion related to the Ouachita event; (6) Jurassic to Early Cretaceous high-angle subduction and compression during the

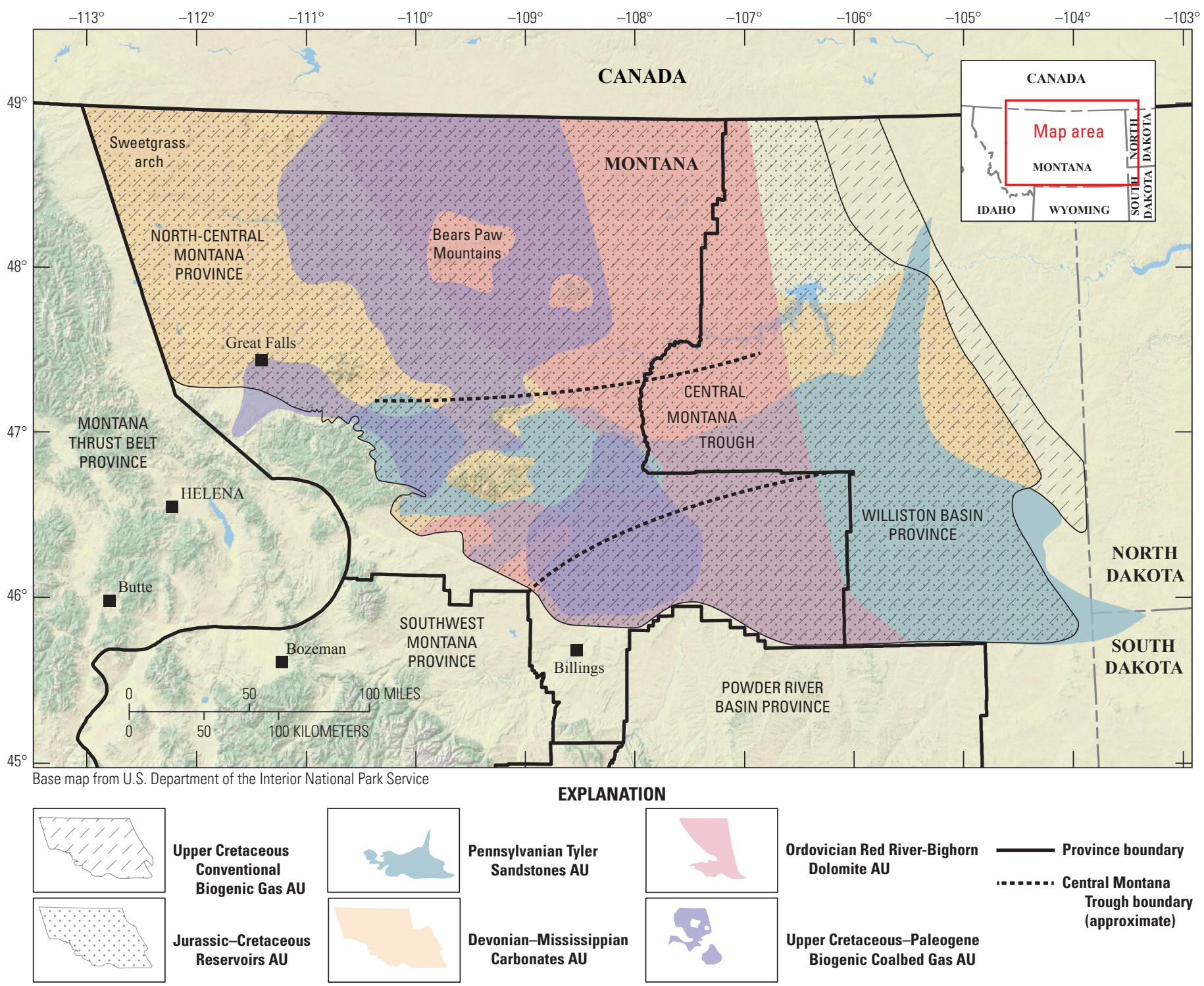

Figure 1. Map showing the location of six assessment units (AUs) in the North-Central Montana Province. 


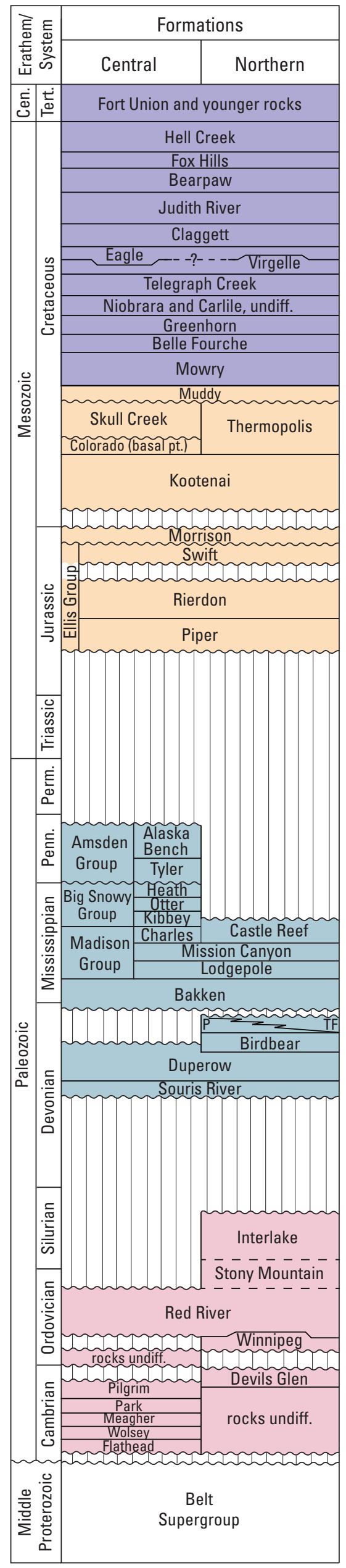

Sevier event; (7) Late Cretaceous through early Tertiary subhorizontal subduction and compression from the Laramide orogenic event; and (8) uplift, erosion, and structural trap formation related to the emplacement of intrusive rocks in the Eocene (Baker and Johnson, 2000). These events shaped the structural and stratigraphic evolution and the development of petroleum systems in the NorthCentral Montana Province (fig. 2).

\section{Total Petroleum Systems and Assessment Units}

The USGS defined four total petroleum systems (TPSs) and six assessment units (AUs) within these TPSs, guided by previous work (Dyman and others, 1995; Anna, 2010). The Upper CretaceousPaleogene Biogenic Gas TPS includes the Upper Cretaceous Conventional Biogenic Gas AU and the Upper CretaceousPaleogene Biogenic Coalbed Gas AU. This TPS is defined by the presence of recoverable biogenic gas contained within shallow sandstone and coal reservoirs (Payenberg and others, 2003; Anna, 2010; Fishman and others, 2012). Gas was generated through biologic processes acting on thermally immature shales and coals, and accumulations of biogenic gas are the principal petroleum resources in the province.

The Jurassic TPS, which includes the Jurassic-Cretaceous Reservoirs AU, is poorly understood, and petroleum source rocks might be present along the flanks of the Sweetgrass arch in the western part of the province (fig. 1). Based on limited data, Jurassic source rocks have total organic carbon (TOC) values up to 3.5 weight percent and contain Type II organic matter (Aram, 1993).

The Devonian-Mississippian Composite TPS may include petroleum source rocks of the Bakken, lower part of the Madison, and the Heath Formations, which were deposited in the central Montana trough. These source rocks contain marine Type II organic matter, have TOC values up to 12 weight percent, and are in the thermal maturity window for oil generation (Jarvie, 2001; Jarvie and others, 2016). Continuous (unconventional) oil resources of the Heath TPS were assessed previously (Drake and others, 2017). The Devonian-Mississippian Composite TPS includes oil in the Pennsylvanian Tyler Sandstones AU and the DevonianMississippian Carbonates AU.
The Ordovician TPS was defined to encompass oil and gas generated from Ordovician marine organic matter in the central Montana trough. Similar Ordovician organic-rich shales in the Williston Basin have TOC values ranging up to 6 weight percent, and hydrogen index values to 800 milligrams of hydrocarbon per gram of total organic carbon (Nesheim, 2017). Thermal maturity of potential Ordovician source rocks is interpreted to be mainly in the oil-generation window. The TPS includes the Ordovician Red River-Bighorn Dolomite AU.

Undiscovered oil and gas resources within the Ordovician TPS and the Devonian-Mississippian Composite TPS are focused within the area of the central Montana trough, as the trough apparently was connected to the Williston Basin during the Ordovician Period through the Mississippian Subperiod.

The assessment input data are summarized in table 1. For the continuous assessment unit, well drainage areas, success ratios, and estimated ultimate recoveries are taken from U.S. coalbed-gas analogs.

\section{Undiscovered Resources Summary}

The USGS quantitatively assessed undiscovered conventional and continuous oil and gas resources in six assessment units within the North-Central Montana Province (table 2). The estimated mean totals for undiscovered resources are 55 million barrels of oil (MMBO) with an F95-F5 range from 0 to $139 \mathrm{MMBO}$; 846 billion cubic feet of gas (BCFG) with an F95-F5 range from 145 to 2,144 BCFG; and 6 million barrels of natural gas liquids (MMBNGL) with an F95-F5 range from 0 to 15 MMBNGL. The estimated mean of $55 \mathrm{MMBO}$ is subdivided as follows: $3 \mathrm{MMBO}$ are in the Jurassic-Cretaceous Reservoirs AU, $7 \mathrm{MMBO}$ are in the Pennsylvanian Tyler Sandstones AU, $25 \mathrm{MMBO}$ are in the Devonian-Mississippian Carbonates AU, and $20 \mathrm{MMBO}$ are in the Ordovician Red River-Bighorn Dolomite AU.

For the Upper Cretaceous Conventional Biogenic Gas AU, the estimated mean is 171 BCFG with an F95-F5 range from 35 to $459 \mathrm{BCFG}$, and in the Upper Cretaceous-Paleogene Biogenic Coalbed Gas AU, the estimated mean is 585 BCFG with an F95-F5 range from 110 to $1,454 \mathrm{BCFG}$. Biogenic gas accounts for about 90 percent of the estimated mean undiscovered, recoverable gas resources in the North-Central Montana Province.

Figure 2. Stratigraphic column for the North-Central Montana Province showing the stratigraphic extent of the four total petroleum systems defined in this study. Modified from Dyman and others, 1995. (Cen., Cenozoic; P, Potlach Formation; Penn.; Pennsylvanian; Perm., Permian; pt., part; Tert., Tertiary; TF, Three Forks Formation; undiff., undifferentiated) 
Table 1. Key input data for six assessment units in the North-Central Montana Province.

[AU, assessment unit; MMBO, million barrels of oil; BCFG, billion cubic feet of gas; \%, percent; EUR, estimated ultimate recovery per well. EUR, well drainage area, and success ratios are defined partly using U.S. coalbed-gas analogs. The average EUR input is the minimum, median, maximum, and calculated mean. Shading indicates not applicable]

\begin{tabular}{|c|c|c|c|c|c|c|c|c|}
\hline \multirow{2}{*}{$\begin{array}{c}\text { Assessment input data- } \\
\text { Conventional AUs }\end{array}$} & \multicolumn{4}{|c|}{ Upper Cretaceous Conventional Biogenic Gas AU } & \multicolumn{4}{|c|}{ Jurassic-Cretaceous Reservoirs AU } \\
\hline & Minimum & Median & Maximum & $\begin{array}{l}\text { Calculated } \\
\text { mean }\end{array}$ & Minimum & Median & Maximum & $\begin{array}{l}\text { Calculated } \\
\text { mean }\end{array}$ \\
\hline Number of oil fields & & & & & 1 & 3 & 10 & 3.2 \\
\hline Number of gas fields & 1 & 10 & 50 & 11.4 & 1 & 2 & 4 & 2.1 \\
\hline Sizes of oil fields (MMBO) & & & & & 0.5 & 1 & 10 & 1.3 \\
\hline Sizes of gas fields (BCFG) & 3 & 6 & 600 & 14.9 & 3 & 6 & 60 & 7.7 \\
\hline AU probability & 1.0 & & & & 0.8 & & & \\
\hline \multirow[b]{2}{*}{$\begin{array}{l}\text { Assessment input data- } \\
\text { Conventional AUs }\end{array}$} & \multicolumn{4}{|c|}{ Pennsylvanian Tyler Sandstones AU } & \multicolumn{4}{|c|}{ Devonian-Mississippian Carbonates AU } \\
\hline & Minimum & Median & Maximum & $\begin{array}{c}\text { Calculated } \\
\text { mean }\end{array}$ & Minimum & Median & Maximum & $\begin{array}{c}\text { Calculated } \\
\text { mean }\end{array}$ \\
\hline Number of oil fields & 1 & 5 & 14 & 5.3 & 1 & 10 & 40 & 11.0 \\
\hline Sizes of oil fields (MMBO) & 0.5 & 1 & 20 & 1.5 & 0.5 & 1 & 100 & 2.5 \\
\hline AU probability & 0.9 & & & & 0.9 & & & \\
\hline \multirow{2}{*}{$\begin{array}{c}\text { Assessment input data- } \\
\text { Conventional AU }\end{array}$} & \multicolumn{4}{|c|}{ Ordovician Red River-Bighorn Dolomite AU } & & & & \\
\hline & Minimum & Median & Maximum & $\begin{array}{l}\text { Calculated } \\
\text { mean }\end{array}$ & & & & \\
\hline Number of oil fields & 1 & 15 & 60 & 16.6 & & & & \\
\hline Number of gas fields & 1 & 3 & 12 & 3.3 & & & & \\
\hline Sizes of oil fields (MMBO) & 0.5 & 1 & 20 & 1.5 & & & & \\
\hline Sizes of gas fields (BCFG) & 3 & 8 & 1,500 & 8.9 & & & & \\
\hline AU probability & 0.8 & & & & & & & \\
\hline \multirow{2}{*}{$\begin{array}{l}\text { Assessment input data- } \\
\text { Continuous AU }\end{array}$} & \multicolumn{4}{|c|}{ Upper Cretaceous-Paleogene Biogenic Coalbed Gas AU } & & & & \\
\hline & Minimum & Mode & Maximum & $\begin{array}{l}\text { Calculated } \\
\text { mean }\end{array}$ & & & & \\
\hline Potential production area of AU (acres) & 400 & $5,507,500$ & $11,015,000$ & $5,507,633$ & & & & \\
\hline Average drainage area of wells (acres) & 40 & 100 & 160 & 100 & & & & \\
\hline Success ratio $(\%)$ & 2 & 7 & 25 & 11.3 & & & & \\
\hline Average EUR (BCFG) & 0.04 & 0.08 & 0.3 & 0.092 & & & & \\
\hline AU probability & 1.0 & & & & & & & \\
\hline
\end{tabular}

Table 2. Assessment results for six assessment units in the North-Central Montana Province.

[MMBO, million barrels of oil; BCFG, billion cubic feet of gas; NGL, natural gas liquids; MMBNGL, million barrels of natural gas liquids. Results shown are fully risked estimates. For gas accumulations, all liquids are included in the NGL category. F95 represents a 95-percent chance of at least the amount tabulated; other fractiles are defined similarly. Fractiles are additive under the assumption of perfect positive correlation. Shading indicates not applicable]

\section{Total petroleum systems and assessment units (AUs)

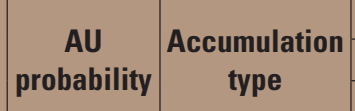 \\ Total undiscovered resources

\begin{tabular}{|c|c|c|c|c|c|c|c|c|c|c|c|}
\hline \\
\hline \multicolumn{4}{|c|}{ Oil (MMBO) } & \multicolumn{4}{|c|}{ Gas (BCFG) } & \multicolumn{4}{|c|}{ NGL (MMBNGL) } \\
\hline$=95$ & \begin{tabular}{|l|} 
F50 \\
\end{tabular} & F5 & Mean & F95 & F50 & F5 & Mean & F95 & F50 & F5 & Mean \\
\hline
\end{tabular}

Upper Cretaceous-Paleogene Biogenic Gas Total Petroleum System

\begin{tabular}{|c|c|c|c|c|c|c|c|c|c|c|c|c|c|c|}
\hline $\begin{array}{l}\text { Upper Cretaceous Conventional Biogenic } \\
\text { Gas AU }\end{array}$ & 1.0 & Gas & & & & & 35 & 128 & 459 & 171 & 0 & 0 & 0 & 0 \\
\hline \multicolumn{15}{|c|}{ Jurassic Total Petroleum System } \\
\hline \multirow{2}{*}{ Jurassic-Cretaceous Reservoirs AU } & \multirow{2}{*}{0.8} & Oil & 0 & 3 & 8 & 3 & 0 & 1 & 2 & 1 & 0 & 0 & 0 & 0 \\
\hline & & Gas & & & & & 0 & 12 & 30 & 13 & 0 & 0 & 0 & 0 \\
\hline \multicolumn{15}{|c|}{ Devonian-Mississippian Composite Total Petroleum System } \\
\hline Pennsylvanian Tyler Sandstones AU & 0.9 & Oil & 0 & 6 & 16 & 7 & 0 & 1 & 3 & 1 & 0 & 0 & 0 & 0 \\
\hline Devonian-Mississippian Carbonates AU & 0.9 & Oil & 0 & 19 & 68 & 25 & 0 & 15 & 55 & 20 & 0 & 0 & 0 & 0 \\
\hline \multicolumn{15}{|c|}{ Ordovician Total Petroleum System } \\
\hline \multirow{2}{*}{ Ordovician Red River-Bighorn Dolomite AU } & \multirow{2}{*}{0.8} & Oil & 0 & 19 & 47 & 20 & 0 & 29 & 76 & 31 & 0 & 6 & 15 & 6 \\
\hline & & Gas & & & & & 0 & 20 & 65 & 24 & 0 & 0 & 0 & 0 \\
\hline Total undiscovered conventional resources & & & 0 & 47 & 139 & 55 & 35 & 206 & 690 & 261 & 0 & 6 & 15 & 6 \\
\hline \multicolumn{15}{|c|}{ Upper Cretaceous-Paleogene Biogenic Gas Total Petroleum System } \\
\hline $\begin{array}{l}\text { Upper Cretaceous-Paleogene Biogenic Coalbed } \\
\text { Gas AU }\end{array}$ & 1.0 & Gas & & & & & 110 & 467 & 1,454 & 585 & 0 & 0 & 0 & 0 \\
\hline Total undiscovered continuous resources & & & & & & & 110 & 467 & 1,454 & 585 & 0 & 0 & 0 & 0 \\
\hline Total undiscovered resources & & & 0 & 47 & 139 & 55 & 145 & 673 & 2,144 & 846 & 0 & 6 & 15 & 6 \\
\hline
\end{tabular}




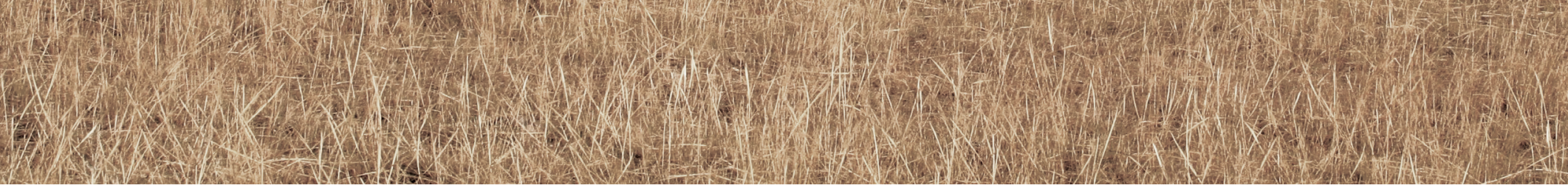

\section{References Cited}

Anna, L.O., 2010, Effects of groundwater flow on the distribution of biogenic gas in parts of the northern Great Plains of Canada and United States: U.S. Geological Survey Scientific Investigations Report 2010-5251, 24 p.

Anna, L.O., Pollastro, R.M., and Gaswirth, S.G., 2011, Williston Basin Province-Stratigraphic and structural framework to a geologic assessment of undiscovered oil and gas resources, chap. 2 of U.S. Geological Survey Williston Basin Province Assessment Team, Assessment of undiscovered oil and gas resources of the Williston Basin Province of North Dakota, Montana, and South Dakota, 2010: U.S. Geological Survey Digital Data Series 69-W, 17 p.

Aram, R.B., 1993, Source rock study of central Montana, in Vern Hunter, L.D., Energy and mineral resources of central Montana: Billings, Montana Geological Society, 1993 Field Conference Guidebook, p. 179-193.

Baker, D.W., and Johnson, E.H., 2000, Tectonic framework and gas-filled structures of the Bearpaw Mountains, NorthCentral Montana, in Schalla, R.A., and Johnson, E.H., eds., Montana/Alberta thrust belt and adjacent foreland, volume II-Road logs, presentation abstracts, and foothills analyses: Montana Geological Society, 50th Anniversary Symposium, Guidebook, p. 1-26.

Drake, R.M., II, Schenk, C.J., Klett, T.R., Le, P.A., LeathersMiller, H.M., Brownfield, M.E., Finn, T.M., Gaswirth, S.B., Marra, K.R., and Tennyson, M.E., 2017, Assessment of undiscovered continuous oil and gas resources in the Heath Formation, central Montana and western North Dakota, 2016: U.S. Geological Survey Fact Sheet 2017-3032, 2 p.

Dyman, T.S., Petersen, J.A., Schmoker, J.W., Spencer, C.W., Rice, D.D., Porter, K.W., Lopez, D.A., Heck, T.J., and Beeman, W.R., 1995, Assessment of undiscovered resources in petroleum plays-U.S. portion of Williston Basin and North-Central Montana: Montana Geological Society, Seventh International Williston Basin Symposium, Guidebook, p. 323-339.
Fishman, N.S., Ridgley, J.L., Higley, D.K., Tuttle, M.L.W., and Hall, D.L., 2012, Ancient microbial gas in the Upper Cretaceous Milk River Formation, Alberta and Saskatchewan-A large continuous accumulation in finegrained rocks, in Breyer, J.A., ed., Shale reservoirs - Giant resources for the 21st century: American Association of Petroleum Geologists Memoir No. 97, p. 258-289.

Jarvie, D.M., 2001, Williston Basin petroleum systemsInferences from oil geochemistry and geology: The Mountain Geologist, v. 38, no. 1, p. 19-41.

Jarvie, D.M.; Lefever, Julie; and Nordeng, S.H., 2016, Madison Group source rocks, Williston Basin, USA: American Association of Petroleum Geologists Search and Discovery Article No. 51301, October 10, 2016, 25 p.

Maughan, E.K., 1989, Geology and petroleum potential, Central Montana Province: U.S. Geological Survey Open-File Report $88-450-\mathrm{N}, 41 \mathrm{p}$.

Nesheim, T.O., 2017, Stratigraphic and geochemical investigation of kukersites (petroleum source beds) within the Ordovician Red River Formation, Williston Basin: American Association of Petroleum Geologists Bulletin, v. 101, no. 9, p. 1445-1471.

Payenberg, T.H.D., Braman, D.R., and Miall, A.D., 2003, Depositional environments and stratigraphic architecture of the Late Cretaceous Milk River and Eagle formations, southern Alberta and north-central Montana-Relationships to shallow biogenic gas: Bulletin of Canadian Petroleum Geology, v. 51, no. 2, p. 155-176.

Petersen, J.A., 1986, General stratigraphy and regional paleotectonics of the western Montana Overthrust Belt, in Petersen, J.A., ed., Paleotectonics and sedimentation in the Rocky Mountain Region, United States: American Association of Petroleum Geologists Memoir No. 41, p. 57-86.

\section{North-Central Montana Province Assessment Team}

Christopher J. Schenk, Tracey J. Mercier, Michael E. Brownfield, Marilyn E. Tennyson, Cheryl A. Woodall, Phuong A. Le, Timothy R. Klett, Stephanie B. Gaswirth, Thomas M. Finn, Janet K. Pitman, Kristen R. Marra, and Heidi M. Leathers-Miller

\section{For More Information}

Assessment results are also available at the USGS Energy Resources Program website at https://energy.usgs.gov. 